\title{
Genetic Variability Correlation and Path Coefficient Analysis of Niger Seed (Guizotia Abyssinica[I.F.] Cass.) Genotypes
}

\author{
Fekadu Amsalu* \\ Holetta Agricultural Research Center, Addis Ababa, Ethiopia
}

*Corresponding Author: Fekadu Amsalu, Holetta Agricultural Research Center, Addis Ababa, Ethiopia.

\begin{abstract}
The experiment was carried out to assess genetic variability, trait association and path coefficient analysis for Niger seed genotypes in order to select the desired plant types for high yield, oil and their components. The experiment was carried out in simple lattice Design in two replications at Ghinchi Agricultural Research Centre. The results of combined analysis indicated that Date of 50\% flowering, date of $50 \%$ maturity, percent oil content and thousand seed weight of studied traits of genotypes for yield and its related component traits were significantly different respectively. This revealed that there was a considerable magnitude of variability among the different genotypes for all the traits except for Seed yield per plot, plant height, stand percent and oil yield. In genetic variability, Heritability, genetic advance genetic advance as percent mean analysis seed yield per plot(11388.054,5574.22485), oil yield per plot(1889.897,898.38763),plant height(151.592,0.062),stand percent(34.302,2.481) showed high phenotypic and genotypic variances, respectively indicating that the genotypes could be reflected by the phenotype and the effectiveness of selection based on the phenotypic performance for these traits. Seed yield per plot (48.948\%), oil yield $(47.536 \mathrm{~kg} / \mathrm{ha})$ and Oil percent $(41.558 \%)$, exhibited high heritability estimates. In genotypic correlation coefficients yield per plot showed significant and positive correlation with oil yield (0.95180), plant height (0.39793) and stand percent (0.59741) which indicates that taking into account these traits as selection parameter will be an effective way to increase seed yield, and oil yield. Analyzed value from genotypic coefficient of variation, heritability and genetic advance, correlation co-efficient and path coefficient, seed yield per plot, oil yield and oil content were the traits which could be considered for future Niger seed crop breeding program.
\end{abstract}

Keywords: Niger seed, genetic variability, heritability, correlation, path analysis.

\section{INTRODUCTION}

Niger (Guizotia abyssinica (L. f.) Cass.)is the only cultivated species of the genus and the most popular and indigenous oil seed crop of Ethiopia grown for its edible oil and seed (Baagoe, 1974).It is characterized by creeping growth habit, yellow flowers, strictly out crossing and self-incompatibility; it is an erect, stout, branched dicotyledonous annual herb with epigeal emergence and diploid chromosome number of 2n=2x=30 (Dagne, 1994; 1995, Geleta et al., 2002 and Geleta and Bryngelsson, 2010). Commercial niger seed is grown in Africa, India and Southeast Asia and the seed is imported around the world as a popular type of birdseed (Adarsh et al., 2014). Niger is contributing 50\% of the oilseed production in Ethiopia and mostly grown by small holder farmers (Geleta et al., 2002). According to CSA, (2017/18) report over 958,213.00 households cultivated on $290,494.94$ ha of land producing over 3,233,448.82 million quintal of niger seed and it is the first widely grown above all oil seed. Niger seed is eaten by mixing with pulse, roasted cereals and flour to make sweet cakes. The oil is used in culinar, paint, soap and as an illuminant. In addition it is used to treat burns and provide protection against cardio vascular disorders and cancer (Adarsh et al., 2014). The press cake is used for livestock feed. Niger meal can also be used as a growth medium for Bacillus species. Ethiopian farmers prefer to growing Niger because of the capability of the crop to grow and giving good seed yield under low soil fertility, moister stress and poor management practices. In addition, niger tolerate crop pests and suitable for soil conservation and rehabilitation (Getinet and Sharma, 1996 and Adarsh et al., 2014).

Despite the crop has originated in Ethiopia and the major oil seed widely growing at different

Regions, it has remained among the poor yielder crops in the country. The national average Productivity is about 0.1113 ton ha-1 (CSA, 2017/18). Its cultivation is overwhelmed by a 
number of critical drawbacks. The major factors are indeterminate growth habit leading to seed Shattering, self-incompatibility, genetically low yielding characteristics, lodging, less or low Responsiveness to management inputs, difficulty of pollination behavior, disease, insect and parasitic weeds.( Teklewold and Wakjira, 2004 ). Niger has received little attention by scientists and considered as underutilized or orphan crop. The availability of limited genetic information and semi domesticated nature of the crop has been an obstacle for further improvement programs (Dempewolf et al., 2008 and 2015). Ethiopian niger is inherently diverse with a broad genetic potential. Exploration of genetic diversity and presence of rich genetic variability in Niger germplasm can open the door for crop improvement and provide new information for the scientific community. To exploit the genetic potential of the crop, understanding the morphological and genetic makeup of the crop for better quality, high yielding and best agronomic traits is very important.

In Ethiopia research on niger seed started in the 1961 by Debre Ziet research station with objective of developing high-yielding niger genotypes in increased of seed yield and oil contents quality traits. During 1967 to 1974 varietal improvement was continued at Holetta and Bako research centers. Since 1984 a multidisciplinary team has been in involved in niger improvement. In doing so the breeding approaches for Ethiopian niger crop improvement remained confined to selection and recombination followed by selection. To address this challenge for a better breeding program, it should have a broad genetic base. The success of any breeding program depends upon the genetic variability existed in the breeding material. The assessment of parameters including phenotypic and genotypic coefficients of variation, heritability in a broad sense, and genetic advance as a percent of the mean is a pre-requisite for making effective selection. The existing genetic base is not enigerh to meet the challenge. Seed yield is a complex character that can be determined by several components reflecting positive or negative effect upon this trait, whereas it is important to examine the contribution of each of the various components in order to give more attention to those having the greatest influence on seed yield (Marjanovic- Jeromela et al., 2007). Clear awareness of the association between yield and its component traits is paramount importance of making the best use of these relationships in selection. Determination of correlation coefficients is an important statistical procedure to evaluate breeding programs for high yield, as well as to examine direct and indirect contributions to yield variables (Ali et al., 2003). Path coefficient technique splits the correlation coefficients into direct and indirect effect i.e., alternative characters or pathways and thus permits a critical examination of components that influence a given correlation and can be helpful in formulating an efficient selection strategy (Sabaghnia et al., 2010). Therefore, correlation in combination with the path coefficient analysis quantifies the direct and indirect contribution of one character upon another (Dewey and Lu, 1959). Hence the present study was conducted to assess the genetic variability, trait association and path coefficient analysis for Ethiopian Niger seed genotypes in order to select desired plant types for high yield, oil and their component traits in central highlands of Ethiopia.

\section{Materials AND Methods}

The experiment was conducted in experimental field at Ghinchi Agricultural Research Centre during 2009/10 cropping season. The test location, Ghinchi Agricultural Research Centre, is the one of testing site for highland niger varieties. It is believed to represent the major crop growing agro ecologies of Ethiopia in the highland areas. The centre is located $45 \mathrm{~km}$ south west of Addis Ababa at altitude of 2200 m.a.s.l. It received an average annual rainfall of $950 \mathrm{~mm}$. Annual temperature ranges $24.10 \mathrm{c}$ to $-8.50 \mathrm{c}$ minimum, is the typical of oil seed growing areas in the central high land. The soil type of the centre is vertisol with difficult drainage system. The experiment was carried out to assess genetic variability, correlation and path analysis of niger genotypes for seed yield, oil content and their component traits of thirty six genotypes of niger seed against two standard checks Kuyu and Shambu. A seed rate of $23 \mathrm{~kg} / \mathrm{ha}$ was utilized to conduct the experiment. Planting was done on $5 \mathrm{July}, 2009$. Two-hand weeding and fertilizer rate of $23 / 23 \mathrm{~N} / \mathrm{P}_{2} \mathrm{O}_{5} \mathrm{Kg} \mathrm{ha}^{-1}$ was the inputs of improved packages used for assessment purpose on each individual experimental plot. Simple Lattice Design with two replications was employed. The gross plot size was nine-meter square (six rows of 5 meter long and $30 \mathrm{~cm}$ spacing) and the net harvest plot size was six-meter square (four central rows). The four central rows in each plot were used for data recording. By considering the central four rows the pre harvested agronomic data such as $50 \%$ date of flowering, 50\%, date of maturity, stand percent and plant height per five plants were recorded. Besides pre harvested data post harvest agronomic data such as number 
of seeds per five plants was counted by seed counter machine, seed yield which was obtained from the central four rows, oil content that was measured by using Nuclear Magnetic Resonance spectroscope, oil yield that was also obtained by multiplying seed yield with corresponding oil percentage and thousand seed weight which was obtained by weighing counted thousand seeds using seed counter machine and were taken and statistically analysed using SAS soft ware. In this experiment ten genotypes of Ethiopian niger seed were randomly taken from different stages of niger trial that were evaluated for the previous season and stocked at Holetta Agricultural Research Centre to represent the available germplasm /breeding stock. These genotypes were originally acquired from the Institute of Biodiversity conservation of Ethiopia and were randomly collections from different regions of Ethiopia.

\section{RESULTS AND DISCUSSION}

Mean performance of thirty six Niger genotypes for eight traits.

As indicated in table 2 significant variations were observed among the genotype for days to flowering, days to maturity and oil content. Days to flowering ranged from 92 to 99 , days to maturity from 141 to 148 and plant height from 122 to $159 \mathrm{~cm}$. The high yielding genotypes, Kuyu, PGRC/E237515/10, collection21and collection45 were 95, 96, 97 days in flowering and maturity dates 146, 142 and 144 respectively. The late flowering date and maturity date for the highest seed yielder was 95 and 145 days respectively. The mean average of seed yield per plots of the tested genotypes ranges from 610kg (for collection 34) to 957 (for kuyu )On the other side oil yield also ranges from $261.52 \mathrm{~kg} / \mathrm{ha}$ (for and PGRC/E 225961/1) to $380.27 \mathrm{~kg} / \mathrm{ha} \mathrm{kg} / \mathrm{ha}$ (for collection21). Alternatively oil content of the tested genotypes ranges from $37.6 \%$ ( for PGRC/E237916/9) to $42.2 \%$ ( for PGRC/E237515/10). .The mean averages of plant height ranges $127 \mathrm{~cm}$ (for PGRC/E 228407/1) to $159 \mathrm{~cm}$ (for collection 3). The stand percent for the tested genotypes ranges from $66 \%$ (for collection10) to $88 \%$ (for collection 20).Thousand seed weight ranges is very narrow. As shown in table2 the tested genotypes,kuyu( $957 \mathrm{~kg} / \mathrm{ha}, 39.1 \%)$,collection21(947 $\mathrm{kg} / \mathrm{ha}, 39.3 \%)$, collection45(911 kg/ha,40.4\%), and PGRC/E237515/10(891kg/ha, 42.4\%) in seed yield and oil yield are first, second third and fourth respectively. In addition only three genotypes (kuyu, collection 21 and collection45) gave the highest seed yield over the mean of the two standard checks respectively. In oil content aspect only one genotype (PGRC/E 237515/10) gave the highest oil content percent, i.e., $42.4 \%$ from all tested genotypes and standard checks. In thousand seed weight PGRC/E237515/6 gave the highest thousand seed weight $(3.72 \mathrm{gm})$ from all tested genotypes. It also ranges from 3.10gm (for PGRC/E 238259/2) to $3.72 \mathrm{gm}$ (PGRC/E237515/6).

Table1. Mean Performance of Thirty Six Genotypes of Niger Seed for Eight Different Traits Studied at Ghinchi Agricultural Research Centre during 2009/10 Cropping Season

\begin{tabular}{|c|c|c|c|c|c|c|c|c|c|}
\hline & & Days to & Seed & Oil & Oil & Height & Stand & TSW \\
\cline { 3 - 10 } No & Genotypes & flowering & Maturity & yield & content & yield & & & \\
\hline 1 & Fogera mutant5/10 & 95 & 146 & 665 & 40.9 & 272.52 & 150 & 72 & 3.2000 \\
\hline 2 & PGRC/E228407/1 & 94 & 144 & 820 & 41.0 & 333.58 & 127 & 72 & 3.4139 \\
\hline 3 & PGRC/E237916/9 & 97 & 144 & 836 & 37.6 & 311.50 & 149 & 81 & 3.2208 \\
\hline 4 & PGRC/E1238259/2 & 97 & 145 & 689 & 38.4 & 255.15 & 141 & 76 & 3.1000 \\
\hline 5 & PGRC/E15013/6 & 95 & 145 & 796 & 38.0 & 301.58 & 149 & 84 & 3.4223 \\
\hline 6 & PGRC/E228406/1 & 95 & 145 & 754 & 37.9 & 284.12 & 146 & 80 & 3.7084 \\
\hline 7 & PGRC/E236374/1 & 99 & 146 & 805 & 39.3 & 319.12 & 148 & 82 & 3.2931 \\
\hline 8 & PGRC/E212722/3 & 96 & 146 & 702 & 39.8 & 281.68 & 129 & 74 & 3.6069 \\
\hline 9 & PGRC/E225962/2 & 94 & 147 & 816 & 40.3 & 330.10 & 141 & 71 & 3.2639 \\
\hline 10 & SPS2001PL\#159/7 & 94 & 147 & 726 & 38.7 & 240.75 & 136 & 71 & 3.3931 \\
\hline 11 & PGRC/E236370/2 & 95 & 146 & 784 & 37.9 & 306.18 & 135 & 79 & 3.4153 \\
\hline 12 & PGRC/E237518/1 & 95 & 148 & 863 & 38.9 & 330.72 & 137 & 77 & 3.4015 \\
\hline 13 & SPS2001PL\#167/1 & 99 & 147 & 787 & 39.1 & 306.16 & 132 & 77 & 3.1569 \\
\hline 14 & PGRC/E237517/9 & 98 & 147 & 722 & 40.7 & 282.72 & 136 & 77 & 3.2208 \\
\hline 15 & SPS2001PL\#183/7 & 93 & 147 & 679 & 38.8 & 274.64 & 131 & 69 & 3.1277 \\
\hline 16 & PGRC/E237516/5 & 95 & 148 & 701 & 38.8 & 269.79 & 141 & 69 & 3.2069 \\
\hline 17 & NRSES(97)PL\#499/6 & 94 & 145 & 808 & 39.7 & 315.22 & 136 & 77 & 3.3292 \\
\hline 18 & PGRC/E237515/6 & 96 & 148 & 749 & 39.9 & 299.26 & 135 & 75 & 3.7153 \\
\hline 19 & PGRC/E238290/1 & 94 & 146 & 786 & 39.7 & 312.39 & 137 & 71 & 3.2500 \\
\hline
\end{tabular}

International Journal of Research Studies in Agricultural Sciences (IJRSAS)

Page $\mid 10$ 
Genetic Variability Correlation and Path Coefficient Analysis of Niger Seed (Guizotia Abyssinica[I.F.] Cass.) Genotypes

\begin{tabular}{|l|c|c|c|c|c|c|c|c|c|}
\hline 20 & PGRC/E237515/10 & 97 & 145 & 891 & 42.4 & 352.95 & 144 & 75 & 3.2139 \\
\hline 21 & PGRC/E200434/1 & 97 & 148 & 685 & 37.5 & 285.87 & 130 & 74 & 3.3208 \\
\hline 22 & PGRC/E225961/1 & 94 & 145 & 704 & 38.8 & 261.52 & 135 & 69 & 3.2000 \\
\hline 23 & PGRC/E235961/6 & 94 & 147 & 779 & 40.3 & 303.95 & 137 & 76 & 3.2223 \\
\hline 24 & Collection10 & 98 & 147 & 726 & 39.2 & 289.99 & 139 & 66 & 3.3584 \\
\hline 25 & Collection55 & 98 & 145 & 680 & 39.8 & 267.21 & 131 & 75 & 3.2708 \\
\hline 26 & Collection22 & 99 & 146 & 714 & 41 & 281.77 & 144 & 72 & 3.4347 \\
\hline 27 & Collection9 & 95 & 141 & 761 & 38.5 & 303.19 & 122 & 71 & 3.2416 \\
\hline 28 & Collection34 & 92 & 146 & 610 & 39.6 & 233.84 & 132 & 79 & 3.1708 \\
\hline 29 & Collection44 & 92 & 147 & 817 & 40.2 & 325.77 & 134 & 87 & 3.3431 \\
\hline 30 & Collection3 & 98 & 145 & 849 & 40.4 & 343.81 & 159 & 80 & 3.2792 \\
\hline 31 & Collection21 & 96 & 142 & 947 & 39.3 & 381.27 & 138 & 84 & 3.2639 \\
\hline 32 & Collection45 & 97 & 144 & 911 & 40.4 & 356.33 & 140 & 81 & 3.3277 \\
\hline 33 & Collection51 & 95 & 141 & 852 & 39.7 & 342.75 & 130 & 80 & 3.2347 \\
\hline 34 & Collection20 & 94 & 145 & 891 & 38.7 & 349.90 & 152 & 88 & 3.5639 \\
\hline 35 & Kuyu & 95 & 146 & 959 & 39.1 & 371.83 & 158 & 85 & 3.2361 \\
\hline 36 & Shambu & 97 & 145 & 849 & 39.1 & 332.87 & 144 & 79 & 3.4223 \\
\hline & Mean & 96 & 146 & 777 & 39.39 & 306 & 139 & 86 & 3.32 \\
\cline { 2 - 9 }$y$ & LSD & 3.48 & 2.93 & 213.46 & 0. & 141.85 & 19.58 & 15.80 & 0.072 \\
\cline { 2 - 9 }$y$ & CV\% & 1.97 & 1.05 & 14.61 & 15.22 & 15.22 & 7.58 & 11.19 & 0.954 \\
\hline
\end{tabular}

The results of combined analysis of mean squares of variance are presented in Table2. The results of combined analysis indicated that studied traits of genotypes for yield and its related component traits were significantly different for all traits compared. This revealed that there was a considerable magnitude of variability among the different genotypes for all the traits studied traits. Similar findings were reported by Suryanarayana L, Sekhar D and Tejeswara Rao K, 2018, The high amount of genetic variability in the studied genotypes for yield contributing traits along with oil content and oil yield indicated that the possibility of further improvement of these traits.

Table2. The Mean Squares for Different Sources Of Variation and the Corresponding Coefficient of Variation in Percent for the Eight Traits Studied.

\begin{tabular}{|c|c|c|c|c|c|}
\hline No. & Traits & Genotypes(35) & Block(10) & Replication(1) & Intra block (25) \\
\hline 1 & Date of flowering & $7.59484^{*}$ & 5.4159 & 7.3472 & 1.559 \\
\hline 2 & Date of maturity & $4.8381^{*}$ & 21 & 8 & 1.587 \\
\hline 3 & Seed yield per plot & $11268.3^{*}$ & 132.031 & 1035361 & 119.8 \\
\hline 4 & Oil content & $1.9016154^{*}$ & 0.03064 & 0.05014 & 0.1753 \\
\hline 5 & Oil yield & $1843.336^{*}$ & 6797.64 & 158860.06 & 46.561 \\
\hline 6 & Plant height & $104.992^{*}$ & 43.292 & 50 & 46.6 \\
\hline 7 & Stand & $19.632^{*}$ & 132.031 & 7.031 & 14.67 \\
\hline 8 & Thousand seed weight & $1.937^{*}$ & 0.0597 & 0.4201 & 0.032 \\
\hline
\end{tabular}

** Indicate significance at 0.01 probability level; ns, non significant, figures in parenthesis refer to degrees of freedom.

\subsection{Genetic Variability, Heritability and Genetic Advance}

Estimates of genotypic and phenotypic variances, genotypic coefficient of variation (GCV), phenotypic coefficients of variation (PCV), heritability in broad sense, expected genetic advances and genetic advances as percent mean are given in Table3. Estimated genetic variance ranged from $0.001 \%$ for thousand seed weight to $5574.2 \mathrm{~kg} / \mathrm{ha}$ for seed yield per plot. Likewise phenotypic variance ranged from $0.065 \%$ for thousand seed weight to 11388.054 for seed yield $\mathrm{kg} / \mathrm{ha}$. Phenotypic coefficients of variation ranged from $1.748 \%$ date of $50 \%$ maturity to $14.207 \%$ for seed oil yield per plot. Genotypic coefficients of variation ranged from $0.879 \%$ for date of $50 \%$ maturity to 9.795 oil yield per plot. Seed yield per plot $(11388.054,5574.2249)$, oil yield $(1889.897,898.387)$ and plant height $(151.592,0.062)$ showed high phenotypic and genotypic variances, respectively indicating that the genotypes could be reflected by the phenotype and the effectiveness of selection based on the phenotypic performance for these traits. 
From tested genotypes of Niger seed low genotypic variance was recorded for traits such as thousand seed weight (0.001) and plant height (0.062). However, high genotypic coefficients of variation (GCV) and phenotypic coefficients of variation (PCV) were shown in traits such as oil yield per $\operatorname{plot}(9.795 \%, 14.207 \%)$ and seed yield per $\operatorname{plot}(9.609 \%, 13.734 \%)$ respectively, which means selection of these traits based on phenotype characteristics may be useful for oil yield and seed yield per plot improvement program. This result agrees with the findings of Thakur. S.K. And Rrddy, R.K., 2012

\subsection{Heritability in the Broad Sense}

Breeders can make rapid progress where heritability is high by using selection methods that are dependant solely on phenotypic characteristics (e.g. mass selection). However, where heritability is low methods of selection based on families and progeny testing are more effective and efficient. Heritability estimated using the total genetic variance is called broad sense heritability .Heritability in the broad sense of the traits is presented in Table 3. In this study, heritability values were found to be sufficiently high for most important yield component characters. Dabholkar (1992) generally classified heritability estimates as low (5-10\%), medium (10-30\%) and high (30-60\%). Based on this classification, seed yield per plot $(48.948 \%)$, oil yield $(47.536 \mathrm{~kg} / \mathrm{ha})$, oil content $(41.558 \%)$ exhibited high heritability estimates. Seed yield per plot was found to be the most heritable trait in the studied genotypes, with heritability of $48.948 \mathrm{~kg} / \mathrm{ha}$ followed by oil yield $(47.536 \mathrm{~kg} / \mathrm{ha})$, oil content percent $(41.558 \%)$ and days to maturity $(29.238 \%)$. This indicates that selection for these traits in the genotype would be most effective for the expression of these traits in the succeeding generations. Therefore, good improvement can be made if some of these traits are considered as selection criteria in future breeding program. Similar findings had been reported by Yared (2010) for seed yield per plot, oil yield, oil content. High heritability value for seed yield per plot, oil yield, oil content recorded in the current study was also recorded by Yared(2010)and Abebe(2006).According to Singh(1993), if the heritability of a character is high, selection for such character is fairly easy as selected character will be transmitted to its progeny. This is because there would be a close correspondence between the genotype and phenotype due to a relatively similar contribution of the environment to the genotype. On the other hand date of 50\% flowering (29.238) and date of maturity (25.295), exhibit medium heritability estimates. Similarly stand percent $(7.233 \%)$, and thousand seed weight $(1.458 \mathrm{gm})$ and plant height $(0.041 \mathrm{~cm})$ exhibit low heritability estimate.

\subsection{Genetic Advance}

Concerning the genetic advance at 5\% intensity the highest genetic gain was predicted for by seed yield per plot oil yield $(107.60 \mathrm{~kg} / \mathrm{ha})$, followed by oil yield per plot $(42.57 \mathrm{~kg} / \mathrm{ha})$ date of $50 \%$ flowering (1.86\%) and while the lowest genetic advance was predicted for thousand seed weight $(0.01 \%)$.Genetic advance as a percent mean ranged from $0.01 \%$ for plant height to $13.91 \%$ oil yield (Table 3). Within this range, a relatively high genetic advance as a percent mean was observed for oil yield per plot (13.91\%) and seed yield per plot (13.85), followed by oil content (3.13\%). On the other hand, the lowest genetic gain as percent of means was observed for plant height $(0.01 \%)$ followed by thousand seed weight $(0.23 \%)$. Low genetic advance as percent means observations in this study indicates that characters probably were under environmental influence than the genotypic expression and that selection based on these traits would be ineffective.

Table3. Estimates of Mean Performance, Range, Genetic Variance (GV),Phenotypic Variance(PV),Genotypic Coefficient of Variation (GCV), Phenotypic Coefficient of Variation (PCV), Heritability and Genetic Advance (GA) in Different Genotypes of Niger Seed.

\begin{tabular}{|c|c|c|c|c|c|c|c|c|c|c|}
\hline No & Traits & Mean & Range & GV & PV & GCV & PCV & H(bs) & GA & $\begin{array}{c}\text { GA } \\
\text { as } \%\end{array}$ \\
\hline 1 & $\begin{array}{c}\text { Date of } \\
\text { flowering }\end{array}$ & 96 & $92-99$ & 2.8024 & 9.585 & 1.744 & 3.225 & 29.238 & 1.86 & 1.94 \\
\hline 2 & $\begin{array}{c}\text { Date of } \\
\text { maturity }\end{array}$ & 145 & $\begin{array}{c}141- \\
148\end{array}$ & 1.6253 & 6.426 & 0.879 & 1.748 & 25.295 & 1.32 & 0.91 \\
\hline 3 & $\begin{array}{c}\text { Seed yield per } \\
\text { plot }\end{array}$ & 777 & $\begin{array}{c}610- \\
959\end{array}$ & 5574.22 & 11388.05 & 9.609 & 13.734 & 48.948 & 107.60 & 13.85 \\
\hline 4 & Oil content & 39.39 & $\begin{array}{c}37.5- \\
42.4\end{array}$ & 0.8631 & 2.077 & 2.359 & 3.659 & 41.558 & 1.23 & 3.13 \\
\hline 5 & Oil yield & 306 & $234-$ & 898.387 & 1889.897 & 9.795 & 14.209 & 47.536 & 42.57 & 13.91 \\
\hline
\end{tabular}


Genetic Variability Correlation and Path Coefficient Analysis of Niger Seed (Guizotia Abyssinica[I.F.] Cass.) Genotypes

\begin{tabular}{|c|c|c|c|c|c|c|c|c|c|c|}
\hline & & & 381 & & & & & & & \\
\hline 6 & Plant height & 139 & $\begin{array}{c}122- \\
159\end{array}$ & 0.062 & 151.592 & 0.179 & 8.8577 & 0.041 & 0.01 & 0.01 \\
\hline 7 & Stand & 76 & $66-88$ & 2.481 & 34.302 & 2.073 & 7.706 & 7.233 & 0.87 & 1.15 \\
\hline 8 & $\begin{array}{c}\text { Thousand seed } \\
\text { weight }\end{array}$ & 3.32 & $3.1-$ & 0.001 & 0.065 & 0.930 & 7.698 & 1.458 & 0.01 & 0.23 \\
& & 3.7 & & & & & & & \\
\hline
\end{tabular}

\subsection{Correlation Coefficient for Ethiopian Mustard Tested Genotypes of Traits}

Genotypic correlation coefficients among yield and its component traits are presented in (table 4). Seed yield per plot showed highly significant and positive correlation with oil yield (r: 0.95180) and stand percent (r: 0.59741), significant with plant height ( $\mathrm{r}$ : 0.39793) which indicates that taking into account oil yield, stand percent and plant height as selection parameter will be an effective way to increase seed, and oil yield. This result is in agreement with the findings of Abebe (2006), Aytac and Kinaci (2009) who reported positive correlation of seed yield per plot with oil yield per plot and seed yield per plant. Oil content percent showed positive non significant correlation with all traits studied except showed negative non significant correlation with stand percent ( $\mathrm{r}:-0.13277)$ and thousand seed weight(r: -0.10628). Oil yield per plot also showed highly and positively association with seed yield (r: 0.95180), Plant height showed positively highly significant correlation with stand percent(r: $0.42900)$ and positive significant correlation with seed yield per plot(r: 0.39793). Hence making simultaneous increase for these characters with yield per plot, oil content and oil yield is difficult. From these results, we may extract that indirect selection for earliness for days to maturity; shortness of plant height will be worthwhile in improvement of the seed and oil yield.

Table4. Genotypic Correlation Coefficients for Combination of Eight Traits in Studied Niger Seed Genotypes.

\begin{tabular}{|c|c|c|c|c|c|c|c|c|}
\hline Traits & SY & $\mathrm{OC}$ & $\mathrm{OY}$ & DF & $\mathrm{DM}$ & $\mathrm{PH}$ & Sta & TSW \\
\hline sy & 1.000 & $\begin{array}{c}0.12627 \\
n s\end{array}$ & $0.95180 * *$ & $0.06191 \mathrm{~ns}$ & $-0.37465^{*}$ & $0.39793 *$ & $0.59741 * *$ & $0.08747 \mathrm{~ns}$ \\
\hline Oc & $0.12627 \mathrm{~ns}$ & 1.000 & $0.23623 \mathrm{~ns}$ & $0.09264 \mathrm{~ns}$ & $0.00135 \mathrm{~ns}$ & $0.0 .02053 \mathrm{~ns}$ & -0.13277 & $\begin{array}{c}0 .-0.10628 \\
n s\end{array}$ \\
\hline oy & $0.95180 * *$ & $\begin{array}{c}0.23623 \\
n s\end{array}$ & 1.000 & $\begin{array}{c}0.09129 \\
\mathrm{~ns}\end{array}$ & $-0.37271^{*}$ & $0.32696 *$ & $0.54269 * *$ & $0.07349 \mathrm{~ns}$ \\
\hline $\mathrm{DF}$ & $0.06191 \mathrm{~ns}$ & $0.09264 \mathrm{~ns}$ & $0.09129 \mathrm{~ns}$ & 1.000 & $\begin{array}{c}- \\
0.01772 \mathrm{~ns}\end{array}$ & $0.23185 \mathrm{~ns}$ & $\begin{array}{c}- \\
0.02251 \mathrm{~ns}\end{array}$ & $0.01183 \mathrm{~ns}$ \\
\hline DM & $-0.37465^{*}$ & $0.00135 \mathrm{~ns}$ & $-0.37271 *$ & $0.01772 \mathrm{~ns}$ & 1.000 & $0.07240 \mathrm{~ns}$ & $\begin{array}{c}- \\
0.26081 \mathrm{~ns}\end{array}$ & $0.13616 \mathrm{~ns}$ \\
\hline $\mathrm{PH}$ & $0.39793 *$ & $\begin{array}{c}0.02053 \\
n s\end{array}$ & $0.32696^{*}$ & $0.23185 \mathrm{~ns}$ & $0.07240 \mathrm{~ns}$ & 1.000 & $0.42900 * *$ & $0.07707 \mathrm{~ns}$ \\
\hline Sta & $0.59741 * *$ & $\begin{array}{c}-0.13277 \\
n s\end{array}$ & $0.426900^{* *}$ & $\begin{array}{c}- \\
0.02251 \mathrm{~ns}\end{array}$ & $\begin{array}{c}- \\
0.26081 \mathrm{~ns}\end{array}$ & $0.42900 * *$ & 1.000 & $0.16236 \mathrm{~ns}$ \\
\hline TSW & $0.08747 \mathrm{~ns}$ & $\begin{array}{c}-0.10628 \\
n s\end{array}$ & $0.07349 \mathrm{~ns}$ & $0.01183 \mathrm{~ns}$ & $0.13616 \mathrm{~ns}$ & $0.07707 \mathrm{~ns}$ & $0.16236 \mathrm{~ns}$ & 1.000 \\
\hline
\end{tabular}

SY seed yield, DF, Date of Flowering, DM: Date of maturity, OC: Oil content, OY: oil yield, PH: plant height, TSW: thousand seed weight.

\subsection{Genotypic Path Coefficient Analysis}

Association of traits determined by correlation coefficient may not provide the exact picture of the relative importance of direct and indirect influence of each yield component traits on yield. Correlation coefficients were partitioned into direct and indirect effect to find out a clear picture of the inter-relationship between yield and other yield related traits by using path analysis. The results of path coefficient analysis for studied traits were indicated in table 5. Path coefficient analysis showed that the oil yield had highest positive direct effect on seed yield per plot (0.38). It had positive indirect effect on seed yield, i.e., oil content percent $(0.28)$, with same value followed by date of flowering $(0.02)$ and plant height $(0.02)$. Also it had negative indirect effect on seed yield i.e., stand percent (0.13 ) and thousand seed weight (-0.02). Finally it made highly significant positive correlation with stand percent and seed yield per plot ( $\mathrm{r} g=0.95180 * *)$. The genotypic correlation of seed yield per plot and oil yield per plot was positive and considerably higher in magnitude. It is mainly due to high positive direct effect and positive indirect effects of other traits. Therefore, selection would be 
effective for seed yield per plot and oil yield. Oil content percent had positive direct effect on seed yield per plot (0.03) and positive highest indirect effect on oil yield (1.51), stand percent $(0.57)$, plant height $(0.38)$, on date of flowering $(0.32)$, date of maturity(0.32and thousand seed weight $(0.02)$. Date of flowering had positive direct effect on seed yield per plot (0.02) and positive indirect effect on oil yield (1.59) followed by stand(0.52), plant height $(0.31)$ and date of maturity (0.31). Date of maturity had positive direct effect on seed yield per plot $(0.01)$ and positive indirect effect on date of flowering $(0.25)$ followed by plant height(0.22), oil yield (0.14), oil content $(0.03))$. Stand percent had positive direct effect on seed yield per plot $(0.41)$ and positive indirect effect on plant height $(0.96)$, oil yield(0.52), date of flowering (0.06), oil content $(0.01)$ ), thousand seed weight $(0.02)$. Stand percent showed the highest positive direct effect (0.96) and positive indirect effect on date of maturity $(-0.06)$. Thousand seed weight had a positive direct effect (0.04) on seed yield per plot and positive indirect effect on stand percent $(0.96)$ followed by oil yield $(0 . .68)$. On other hand thousand seed weight had highest negative indirect effect on oil content $(-0.04))$, date of days to flowering (-0.01). It was observed to have high positive in direct effects on stand percent (0.96) and oil yield (0.68) but its influence was invalidate by the negative indirect effects with days to flowering (-0.01) and oil content $(-0.04)$, which resulted non-significant negative correlation with seed yield per plot $(\mathrm{rg}=0.08747 \mathrm{~ns})$.

The path coefficient analysis indicated that date of flowering, oil content, stand percent, oil yield per plot, thousand seed weight and plant height were the most important contributors to seed yield per plot which could be taken in to consideration for future breeding program. Wide variability has been found among the genotypes for all the traits. The result of the study will provide the ability of breeders to develop desirable plant types having high seed yield, oil content and oil yield with early maturity. Analyzed value from genotypic coefficient of variation, heritability and genetic advance in percent of mean, correlation co-efficient and even path coefficient indicates oil content, oil yield, seed yield per plant, date of flowering, date of maturity, plant height and thousand seed weight were such traits which could be considered for future Niger seed crop breeding program.

Table5. Genotypic Path Coefficient Analysis Showing Direct (Bold) and Indirect Effects of Different Traits in Niger Genotype.

\begin{tabular}{|c|c|c|c|c|c|c|c|c|}
\hline & OC & OY & DF & DM & PH & Stand & TSW & SY \\
\hline OC & $\mathbf{0 . 0 3}$ & 1.51 & 0.02 & 0.32 & 0.38 & 0.57 & 0.02 & $0.126 \mathrm{~ns}$ \\
\hline OY & 0.28 & $\mathbf{0 . 3 8}$ & 0.02 & 0.00 & 0.02 & -0.13 & -0.02 & $0.952^{* *}$ \\
\hline DF & 0.07 & 1.59 & $\mathbf{0 . 0 2}$ & 0.31 & 0.31 & 0.52 & 0.02 & $0.062 \mathrm{~ns}$ \\
\hline DM & 0.03 & 0.14 & 0.25 & $\mathbf{0 . 0 1}$ & 0.22 & -0.02 & 0.00 & $-0.375^{*}$ \\
\hline PH & 0.00 & -0.59 & 0.00 & -0.85 & $\mathbf{0 . 0 7}$ & -0.25 & 0.03 & $0.398^{*}$ \\
\hline Stand & 0.01 & 0.52 & 0.06 & -0.06 & 0.96 & $\mathbf{0 . 4 1}$ & 0.02 & $0.597 * *$ \\
\hline TSW & -0.04 & 0.68 & -0.01 & 0.22 & 0.41 & 0.96 & $\mathbf{0 . 0 4}$ & $0.087 \mathrm{~ns}$ \\
\hline
\end{tabular}

Sy: seed yield, Oc: Oil content, OY: oil yield, SYPPL: seed yield per plant, DF, Date of flowering, DM: Date of maturity, PB: primary branch, SB: secondary branch, PH: plant height, ns: number of seeds, TSW: thousand seed weight.

\section{CONCLUSION}

The present study was carried out to assess the genetic variability, trait association and path coefficient analysis for Niger seed genotypes which are very important for an effective breeding program to select desired plant types to meet the arising demand for high seed yield, oil content and their component traits in central highlands of Ethiopia. Studied traits of genotypes for seed yield and its related component traits were significantly different for all of traits studied. This revealed that the presence of a considerable magnitude of variability among the different genotypes of Niger for all the traits studied.

The high amount of genetic variability in the studied genotypes for yield contributing traits along with oil content and oil yield indicated that the existing possibility for the further improvement of these traits. Phenotypic correlation coefficients were higher in magnitude than their respective genotypic correlation coefficients for most of the traits indicating the environmental influence on phenotypic expression. In genotypic correlation coefficients analysis seed yield per plot showed highly significant 
and positive correlation with oil yield, with date of maturity and date of flowering which indicates that taking into account oil yield, flowering date, maturity date, as selection parameter will be an effective way to increase seed, and oil yield. In the path coefficient analysis indicated that date of flowering, stand percent, thousand seed weight and plant height were the most important contributors to seed yield per plot which could be taken in to consideration for future breeding program. Wide variability has been found among the genotypes for all the characters. The result of the study will provide the ability of breeders to develop desirable plant types having high seed yield and oil yield with early maturity. Analyzed value from genotypic coefficient of variation, heritability and genetic advance in percent of mean, correlation co-efficient and even path coefficient, oil yield, seed yield per plant, date of flowering, date of maturity and plant height were the such traits which could be considered for future mustard crop breeding program.

\section{REFERENCES}

[1] Abebe D (2006). Genetic Variability and Association Among Seed Yield and Yield Related Traits in Ethiopian mustard (Brassica carinata A. Braun) at Kulumsa, Arsi. An M.Sc. Thesis Presented to the School of Graduate Studies of Alemaya University.

[2] Adarsh, M.N., Poonam, K. and Shilpa, D., 2014. A review of Guizotia abyssinica : A multipurpose plant with an economic prospective. Journal of Industrial Pollution Control. 30(2): 277-280.

[3] Anderson, J. A., Churchil, G. A., Autrique, J. E., Tanksley, S. O. and Sorrels, M. E. 1993.

[4] Optimizing parent selection for genetic linkage maps. Genome. 36: 181-186.

[5] Aremu, C.O., 2011. Genetic diversity: A review for need and measurements for inter species crop improvement. Journal of Microbial Biotech Research. 1(2): 80-85.

[6] Aytaç Z, Kınac G (2009). Genetic variability and association studies of some quantitative characters in winter rapeseed(Brassica napus L.). African Journal of Biotechnology, 8 (15): 3547-3554

[7] Baagøe, J., 1974. The genus Guizotia (Compositae) a taxonomic revision. Botanisk Tidsskrift.69:1-39

[8] CSA, 2017/18. The Federal Democratic Republic of Ethiopia Central Statistical Agency report on area and production of major crops.Addis Ababa, Ethiopia.

[9] Dabholkar AR (1992). Elements of biometrical genetics. Concept Publishing Company, New Delhi, India.431p.

[10] Dewey DR, KH (1959). A correlation and path coefficient analysis of components of crested wheat grass seed production. J. Agron. 51:515-518

[11] Teklewold, A. and Wakjira, A., 2004. Seed filling and oil accumulation in noug (Guizotia abyssinica (L.f.) Cass).Sinet Ethiopian Journal of Science. 27(1): 25-32.

[12] Dempewolf, H., Tesfaye, M., Teshom, A., Bjorkman, A.D., Andrew, R.L., Scascitelli, M., Black, S., Bekele, E., E., Engels, J.M., Cronk, Q.C. and Rieseberg, L.H., 2015. Patterns of domestication in the Ethiopian oilseed crop noug (Guizotia abyssinica). EvolutionaryApplications.8 (5):464-474.

[13] Dagne, K., 1994. Meiosis in interspecific hybrids and genomic interrelationships in GuizotiaCass. (Compositae). Hereditas. 121:119-129

[14] Dagne, K., 1995. Karyotypes C-banding and nucleolar numbers in Guizotia (Compositae). Plant Systematics and Evolution. 195: 121-135.

[15] Geleta, M., Bryngelsson, T., Bekele, E. and Dagne, K., 2008. Assessment of genetic diversity of Guizotia abyssinica (L.f.) Cass. (Asteraceae) from Ethiopia using amplified fragment length polymorphism. Plant Genetic Resources. 6: 41-51.

[16] Adarsh, M.N., Poonam, K. and Shilpa, D., 2014. A review of Guizotia abyssinica : A multipurpose plant with an economic prospective. Journal of Industrial Pollution Control. 30(2): 277-280.

[17] Geleta, M., Asfaw, Z., Bekele, E., Teshom, A., 2002. Edible oil crops and their integration

[18] With the major cereals in North Shewa and South Wollo central highlands of Ethiopia: an ethno botanical perspective. Hereditas. 137: 29-40.

[19] Suryanarayana L, Sekhar D and Tejeswara Rao K2018. Studies on genetic variability, character association and path analysis in Niger ( Guizotia abyssinica $\quad$ L. ) Genotypes. JPP 2018; 7(4): 3339-3341

[20] Thakur, S.K. and Rrddy, R.K., Genetic variability, correlation and path analysis in niger, Guizotia abyssinica cass. Journal of Oil seeds Research, 29(1): 31-33 (2012). 
[21] Yared S (2010). Genetic diversity and Relationship among Association among Ethiopian mustard (Brassica carinata A. Braun) genotypes based on their agronomic and quality Traits in Holetta Agricultural research, M.Sc. Thesis presented to the School of Graduate Studies of Jima University.

Citation: Fekadu Amsalu, "Genetic Variability Correlation and Path Coefficient Analysis of Niger Seed (Guizotia Abyssinica[I.F.] Cass.) Genotypes” International Journal of Research Studies in Agricultural Sciences (IJRSAS), 2020; 6(3), pp. 8-16, http://dx.doi.org/10.20431/2454-6224.0603002.

Copyright: (C) 2020 Authors. This is an open-access article distributed under the terms of the Creative Commons Attribution License, which permits unrestricted use, distribution, and reproduction in any medium, provided the original author and source are credited. 